\title{
Towards a Plastic Circular Economy: Bio-derived Plastics and their End-of-life Strategies
}

\author{
Simon B. C. Verstraeten ${ }^{\mathrm{ab}}$, Antoine van Muyden ${ }^{\mathrm{ab}}$, and Felix D. Bobbink ${ }^{\mathrm{a} \star}$
}

\begin{abstract}
Herein, we describe the status of bio-derived plastics as well as the existing and emerging technologies that are available for their post-consumer end-of-life valorization. We first present how bio-derived plastics can be produced from renewable materials such as biomass and $\mathrm{CO}_{2}$. In the second section, we present an overview of the technologies available for the end-of-life, including pyrolysis and gasification and how they can be leveraged towards a circular economy. We continue the discussion with the presentation of an emerging technology, polyolefin hydrocracking. Finally, the concepts are discussed in light of life cycle analysis that helps to assess the sustainability of manufacture (and recycling) methods.
\end{abstract}

Keywords: Biodegradable plastics · Catalysis · Circular economy · Renewable plastics

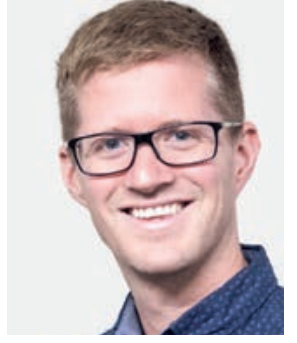

Felix Bobbink holds a PhD from the Ecole Polytechnique Fédérale in the field of catalysis (2018). After his PhD, he co-founded the company Plastogaz based on one of his inventions. His company develops catalysts for the transformation of plastic waste into value-added products. Dr. Bobbink has published over 25 articles $(\mathrm{h}$-index $=16$ ) and is listed as an inventor in 2 patent applications.

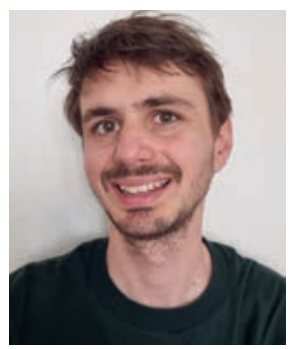

Antoine van Muyden holds a $\mathrm{PhD}$ from the Ecole Polytechnique Fédérale in the field of catalysis for biomass valorization $(2020,14$ articles). After his $\mathrm{PhD}$, he co-founded the company Plastogaz based on his invention. Dr. van Muyden leads the development of the catalytic hydrocracking process that he invented together with Dr. Bobbink.

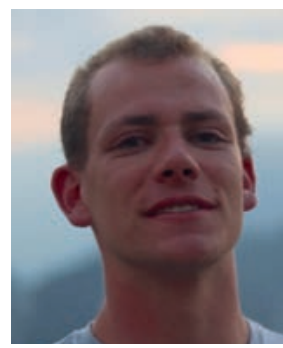

Simon Verstraeten is a MSc student in chemical engineering at the Ecole Polytechnique Fédérale. At Plastogaz, Simon works as a research engineer where he participates in the development of chemical recycling technologies.

\section{Introduction}

Plastic is a generic term for synthetic polymers that can be shaped and moulded in various forms leading to broad consumer applications. Since the first commercial applications of plastics in the early $20^{\text {th }}$ century, ${ }^{[1]}$ their production has increased exponentially to reach a staggering 400 MTon annual production in 2020

${ }^{*}$ Correspondence: Dr. F. D. Bobbinka ${ }^{a}$ E-mail: felix.bobbink@plastogaz.com aPlastogaz SA, EPFL Innovation Park Batiment C, CH-1015 Lausanne;

'Ecole Polytechnique Fédérale de Lausanne, CH-1015 Lausanne, Switzerland
(Fig. 1). [2] Plastics play an important role in our daily lives as they are used for packaging, construction, piping and more. Owing to their tunability, many different types of plastics were synthesized and found commercial applications. The most widespread resins today are polyethylene (PE), polypropylene (PP), polystyrene (PS), polyvinyl chloride (PVC), polyethylene terephthalate (PET), and polyurethanes (PUR). ${ }^{[3]}$ Other important plastics include polycarbonates, polytetrafluoroethylene (PTFE), polymethylmethacrylate (PMMA) and polyamides such as Nylon. ${ }^{[4]}$ Today, the vast majority of plastics are prepared from non-renewable resources $(\sim 99 \%)$ but a growing fraction of plastics (usually polylactic acid (PLA) and PE) can now be produced from renewable feedstocks. ${ }^{[5]}$

After their utilization, plastics are disposed and the major fraction is either landfilled or incinerated $(>90 \%)$ and only $10 \%$ is recycled. ${ }^{[6]}$ Landfilling and incineration are convenient and cheap but lead to environmental pollution and greenhouse gas (GHG) emissions. This linear consumption model is a waste of resources. Recycling on the other hand requires arduous or sophisticated collection and sorting methods. The successive melting and re-shaping of recycled plastics diminish the quality compared to virgin grade. These complications often prevent their utilization in food contact applications. ${ }^{[7]}$ To overcome this challenge, chemical recycling methods have been proposed, wherein the polymer bonds are broken down into their monomers before being polymerized again into virgin quality plastics. ${ }^{[8]}$ The definitions of chemical recycling and chemical upcycling are, respectively, the conversion of polymers into the original monomers, and into fuels or other valuable chemicals. ${ }^{[9]}$ Note that there is a lack of consensus on the terminology of certain technologies. Chemical recycling and upcycling can be achieved with several technologies such as pyrolysis (thermal treatment in the absence of oxygen), gasification (controlled oxidation into syngas) or hydrocracking (catalytic treatment in the presence of hydrogen). ${ }^{[10]}$ The latter requires the development of finely tuned catalysts that are feedstock tolerant and ensure a narrow selectivity under mild reaction conditions. ${ }^{[11]}$

In this review, we present different renewable polymers production routes, the status of the technologies, and the possibilities for these materials at the end-of-life, with a focus on hydrocracking, an emerging technology. The structure of the review starts with stating the current situation of plastic utilization and production before moving to alternative production methods from renew- 
Fig. 1. a) World production of plastic resins from 1950 to 2015.

b) Contribution of each resin type to the world production.

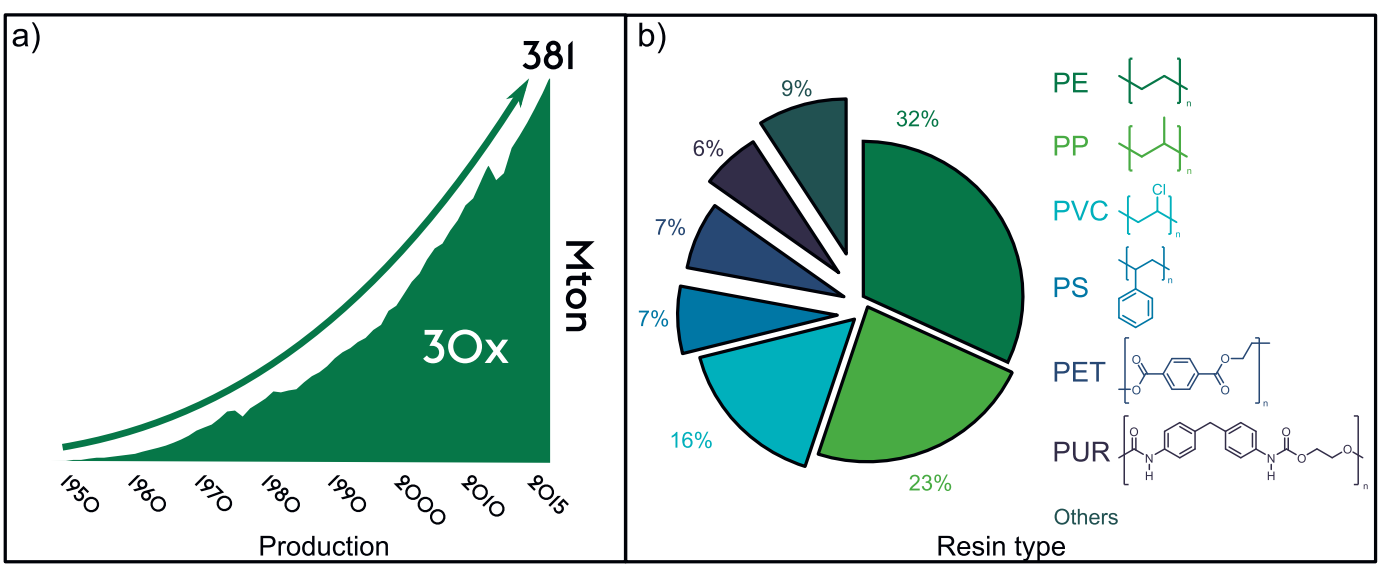

able sources. Then, we cover methods for end-of-life valorization as these are an essential part of the circular economy. Finally, the importance of thorough life cycle analysis is highlighted in the case of short-lived plastics recycling. The scope of the review is limited to the main plastics in the market (PE, PP, PET and PVC) but other types of plastics will be briefly mentioned to familiarize the reader with the extent of the possibilities in the field.

\section{Bio-derived Polymers Production Routes}

\subsection{Status and Strategies}

The traditional production of polyolefins derives from the utilization of crude oil, specifically ethylene, propylene and styrene to make PE, PP, PVC and PS. ${ }^{[12]}$ As seen in Fig. 1, PE and PP dominate the marketplace ( $\sim 50 \%$ of market share). Since polyolefins are non-biodegradable and often derived from non-renewable sources, there have been attempts to improve their sustainability.

A first strategy is to replace polyolefins by biodegradable polymers. One notable example is polyethylene furanoate (PEF) as a replacement to PET (structures depicted in Scheme 1). ${ }^{13]}$ Bottle-grade PEF can be achieved and displays improved barrier properties with respect to oxygen, carbon dioxide and water, but lower thermal stability compared to PET. ${ }^{[14]}$ This reduced thermal resistance, combined with long reaction time, prevents its synthesis by standard polycondensation-based processes, but effective routes are being developed by ring-opening polymerization. ${ }^{[15]}$ Regarding commercial applications, Avantium (The Netherlands) has currently reached pilot scale for PEF production ${ }^{[16]}$ and intends to further scale-up its technology starting in 2023.

Another strategy, to improve the sustainability of plastics while maintaining their properties, is to change the origin of the feedstock to renewable resources (e.g. non-edible biomass or $\left.\mathrm{CO}_{2}\right){ }^{[17]}$ In this way, with the exception of the production method, the rest of the value chain is kept unmodified and their impact at the end-of-life is reduced. ${ }^{[18]}$

On a side note, the term 'bio-plastics' should be used cautiously, as it can represent a plastic that originates from a renewable feedstock source, a plastic that is biodegradable, or even a plastic that both comes from renewable feedstock and is biode-

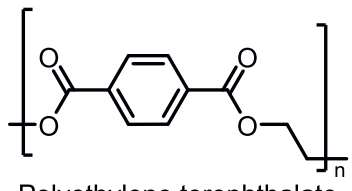

Polyethylene terephthalate

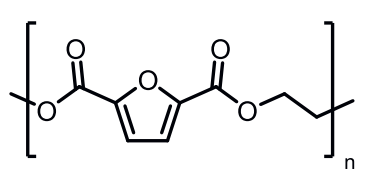

Polyethylene furanoate gradable. ${ }^{[19]}$ Therefore, the terms bio-sourced and biodegradable plastics should be preferred to bio-plastics to prevent misleading consumers.

\subsection{Bio-sourced Plastics}

In the context of renewable feedstocks for chemical applications, the term biomass often relates to cellulosic materials even though other fractions of biomass can also be valorized, such as lignin (bio-polymer present in wood), either biologically[20] or chemically (Fig. 2), ${ }^{[21]}$ and chitin (bio-polymer present in marine life). ${ }^{[22]}$

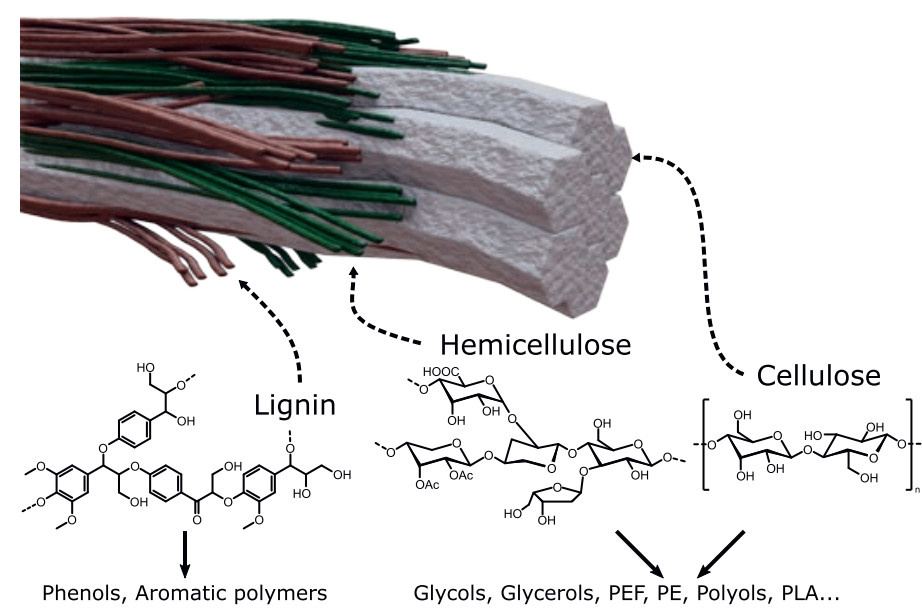

Fig. 2. Woody biomass structure and several applications for polymer production (adapted from ref. [23]).

One interesting application is the transformation of cellulosic materials into polyethylene via fermentation. In this approach, the cellulose is first converted by microbial digestion into bioethanol under anaerobic conditions. ${ }^{[24]}$ The bio-ethanol is then dehydrated under high temperature over an acid catalyst to form ethylene. ${ }^{[25,26]}$ The bio-sourced ethylene is then substituted in the production of PE. One production method consists in using sugar cane as cellulosic feedstock. ${ }^{[24]}$

Cellulose can also be converted into 5-hydroxymethylfurfural, which in turn can be converted into the diacid FDCA, PEF's precursor (Scheme 2, left). There have been propositions to directly convert cellulose into 5-HMF, e.g. using ionic liquids combined with metal salts as catalysts, but this pathway results in a challenging 5-HMF isolation, as well as modest yields. ${ }^{27]}$ When glucose is used as the starting material, optimizing reaction conditions is more facile and catalysts are required to promote the isomerisation of glucose into fructose 
before it can be converted into 5-HMF. ${ }^{[28-30]}$ In fact, the reaction proceeds very smoothly when D-fructose is used as the starting material.

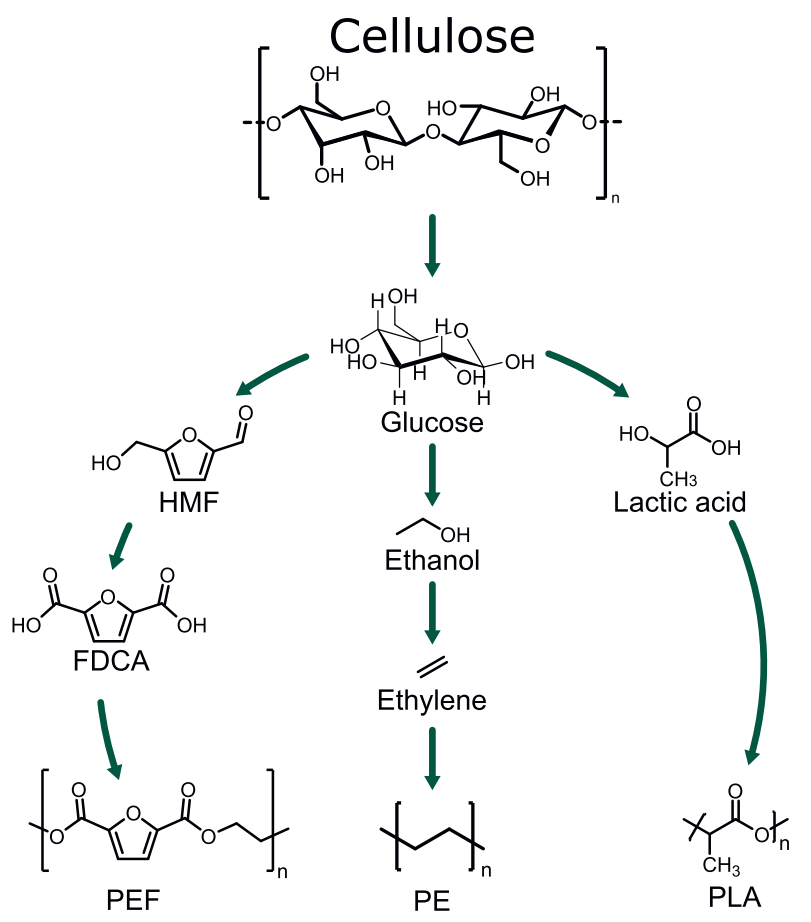

Scheme 2. Transformation of cellulose to bio-sourced polymers. Cellulose is first transformed into glucose. Left: PEF pathway through dehydration, oxidation and polymerisation with mono ethylene glycol. ${ }^{[3]}$ Middle: PE pathway through fermentation into ethanol, catalytic dehydration to ethylene and polymerisation. ${ }^{[24-26]}$ Right: PLA pathway through fermentation ${ }^{[35]}$ or catalytic conversion ${ }^{[32]}$ into lactic acid, and azeotropic dehydration condensation or cyclisation followed by ring-opening polymerization. ${ }^{[36]}$

Another fermentation pathway for cellulose results in lactic acid. First, the cellulose must be hydrolyzed. The resulting glucose is then converted into lactic acid, typically through a fermentation process. ${ }^{[31]}$ Chemical approaches for the transformation of glucose and cellulose into lactic acid have also been proposed, e.g. by using lead catalysts. ${ }^{[32]}$ The lactic acid can then be polymerized through polycondensation in PLA (Scheme 2, right). ${ }^{33}$

It is interesting to note, there are a plethora of other examples of polymers derived from bio-sourced origin, including for example polyhydroxyalkanoates (PHA), polyglycolic acid, and more that have been reviewed extensively elsewhere. ${ }^{[37,38]}$ These polymers are being researched for utilization in biomedical applications, e.g. sutures or stents.

\section{$2.3 \mathrm{CO}_{2}$-based Plastics}

Another promising renewable route for the synthesis of plastics is via $\mathrm{CO}_{2}$ utilization. The $\mathrm{CO}_{2}$ can originate from direct air capture (DAC) initiatives, which consist in filtering the atmospheric $\mathrm{CO}_{2}$ and concentrating it, ${ }^{[39]}$ or carbon capture and storage (CCS) units, which consist in capturing the $\mathrm{CO}_{2}$ at the source, where large amounts are produced. ${ }^{40]}$ Both DAC and CCS are energy intensive processes and research is ongoing in the development of $\mathrm{CO}_{2}$ capturing materials (e.g. amine solvents, solid sorbents, and others). ${ }^{411]}$ Since DAC is an emerging technology, its price is still not competitive with the $\mathrm{CO}_{2}$ emission market but recently, large investments have been made to develop the technology (e.g. Climeworks, a Swiss company that raised over $100 \mathrm{MCHF})^{[42]}$ CCS units are typically installed at the exhaust of large production plants (i.e. post-combustion CCS). There are examples of CCS working at commercial scale in Northern Europe ${ }^{[43]}$ and North America, ${ }^{[44]}$ wherein the captured $\mathrm{CO}_{2}$ is typically injected deep underground, although the $\mathrm{CO}_{2}$ is sometimes used for other applications such as in greenhouses to improve crop yields. With CCS, the costs are lower as the $\mathrm{CO}_{2}$ concentration is much higher than in the atmosphere and large-scale technologies are already available, e.g. with amine scrubbing. ${ }^{[45]}$ Many approaches are currently being studied to valorize $\mathrm{CO}_{2}$, such as the production of polyolefins as described in Fig. 3.

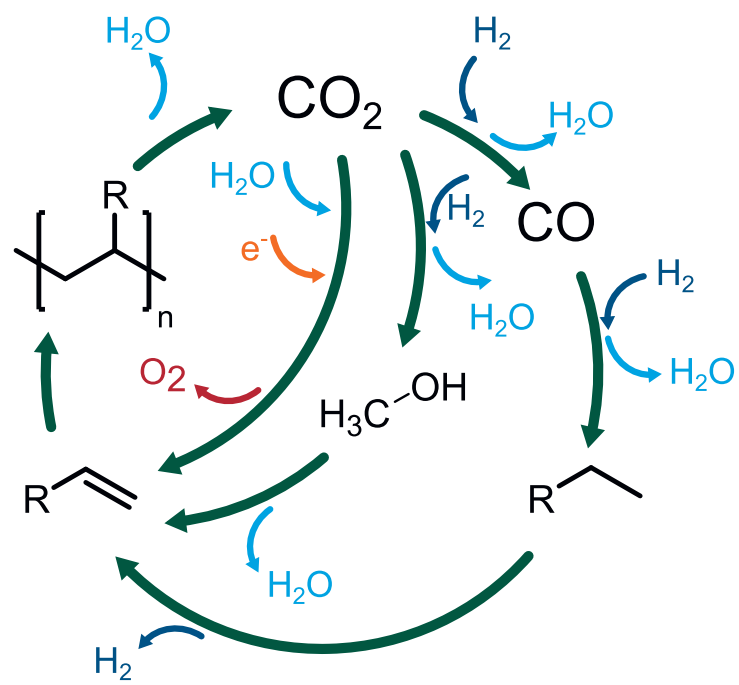

Fig. 3. The three main pathways to produce polyolefin from carbon dioxide. Stoichiometry is omitted for clarity. $\mathrm{R}=\mathrm{H}$ or alkane chain.

One promising approach for the transformation of $\mathrm{CO}_{2}$ into ethylene, PE precursor, is via electrochemical reduction in water using copper oxide as catalyst. ${ }^{[46-48]}$ Many mechanisms have been proposed for the $\mathrm{CO}_{2}$ reduction reaction $\left(\mathrm{CO}_{2} \mathrm{RR}\right)$ and the pathways remain unclear to date. ${ }^{[49]}$ However, it has been established that surface-adsorbed $\mathrm{CO}(* \mathrm{CO})$ is the key intermediate in the process and participates to $\mathrm{C}-\mathrm{C}$ bond formation. ${ }^{[50]}$ The reaction conditions, such as $\mathrm{pH}$, applied potential, catalyst composition and structure, etc., drastically influence the intermediate stabilities and modify the yields and the selectivities. ${ }^{[49]}$

This process is very attractive as it consumes $\mathrm{CO}_{2}-\mathrm{a}$ greenhouse gas - while producing a valuable chemical. However, the efficiency is not excellent. One of the best catalysts at laboratory scale achieves a $70 \%$ Faradaic efficiency towards ethylene but a full-cell energy efficiency of only $34 \% .{ }^{[47]}$ As far as we are aware, this technology has not yet been implemented industrially and it requires further development at laboratory scale before scaling up to more ambitious initiatives at pilot and industrial scale.

Key challenges in $\mathrm{CO}_{2}$ electroreduction are associated with scaling up the technology. Indeed, standard electrochemical cells that are common at laboratory scale are not always suitable at larger scale. The reactor design is therefore a critical step of the process, along with the development of more efficient catalysts. ${ }^{51,52]}$ Nevertheless, water electrolysis to produce $\mathrm{H}_{2}$ and $\mathrm{O}_{2}$ is being scaled up rapidly and is commonly used in power-to-gas $\left(\mathrm{CO}_{2}\right.$ methanation using Green $\mathrm{H}_{2}$ ) applications. [38]

Other approaches to valorize $\mathrm{CO}_{2}$ involve the electrochemical reduction of $\mathrm{CO}_{2}$ to $\mathrm{CO}$, and the subsequent Fischer-Tropsch (FT) reaction with hydrogen to produce alkanes. ${ }^{[53]}$ The FT process is well-documented and catalysts can be optimized to produce short chain paraffins that can be used for plastic production applications. ${ }^{[54]}$ The first step, however, is typically an electrochemical reduction that faces the same challenges as the direct reaction to ethylene. 
$\mathrm{CO}_{2}$ can also be reduced into methanol which can be catalytically transformed to produce olefins through a methanol-toolefins (MTO) process. ${ }^{[55,56]}$ The first reduction step is conducted industrially by using a mixture of $\mathrm{CO}_{2}, \mathrm{CO}$ and $\mathrm{H}_{2}$ over a catalyst, typically $\mathrm{Cu} / \mathrm{ZnO}$, even if other structures, e.g. containing gallium, have been proposed. ${ }^{[57,58]}$ The transformation of methanol into olefins requires molecular sieves as catalyst, the most widespread one being silicoaluminophosphate SAPO-34. [59] The latter displays high selectivity towards light olefins and is already used in multiple pilot and industrial (MTO) applications. ${ }^{[60]}$

There are also efforts to produce valuable materials (polymers) from $\mathrm{CO}_{2}$ using microorganisms. For example, polyhydroxyalkanoates (PHA) are naturally occurring biodegradable polyesters produced by bacteria and displaying similar properties to $\mathrm{PE}$ and PP. ${ }^{[61]}$ In particular, polyhydroxybutyrate (PHB), the most common PHA, can be synthetised from $\mathrm{H}_{2}$ and $\mathrm{CO}_{2}$, by Cupriavidus necator, a hydrogen-oxidising bacterium, with high yields (up to $70 \%$ of its mass). ${ }^{[62]}$ These bacteria are chemolithotrophic which means that they process $\mathrm{CO}_{2}$ as sole carbon source (autotrophic), and use an inorganic source of energy (in this case hydrogen). Furthermore, these bacteria can be cultured under heterotrophic conditions, with organic molecules as energy and carbon source, enabling fast population growth before switching to autotrophic conditions and PHB production. [63] Researchers have even succeeded in genetically engineering fast growing photosynthetic cyanobacteria to produce PHB to render the process photoautotrophic. ${ }^{[64]}$ Nevertheless, current studies have been limited to $10 \mathrm{~L}$ bioreactors, which makes the techno-economic potential of the technologies challenging to assess. ${ }^{61,64]}$

\section{Post-consumption Valorization Methods}

The transition from a linear to a circular economy will require an improvement of the waste management system as well as the development of new technologies. From a collecting and sorting standpoint, technologies and incentives must be created to lower the cost of the processes. ${ }^{[65]}$ This would provide sufficiently pure feedstock to be further processed by valorization technologies other than landfilling and incineration. Fig. 4 provides a simplified overview of the plastic value chain from its production to consumption to waste treatment and contains the technologies that have the potential to afford a circular economy.

When possible, mechanical recycling should be preferred because it consumes less energy and results in the lowest carbon footprint.[66] This is due to the fact that no chemical bonds are broken during the process, unlike for chemical recycling. Nevertheless, in many instances, the quality of the feedstock is too poor to be handled by mechanical recycling methods, ${ }^{[67]}$ and in these instances chemical recycling will have a role to play.

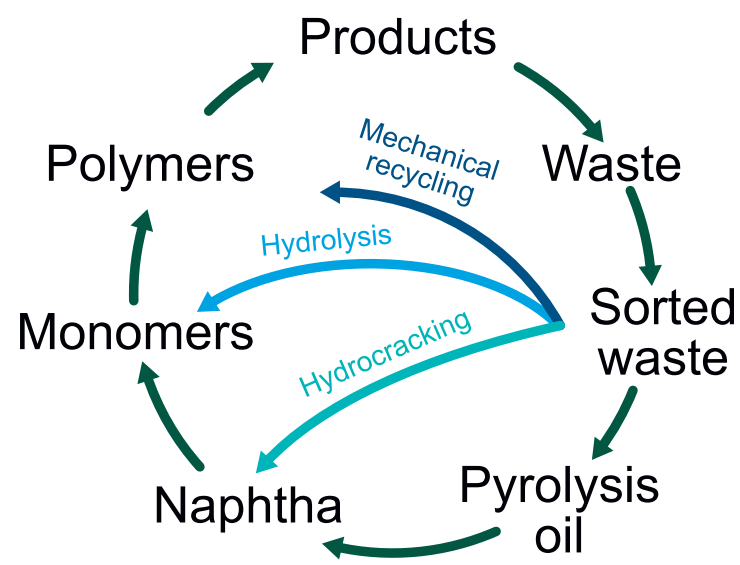

Fig. 4. Schematic representation of the plastic value chain. Today, most of the value is lost as the plastics exit the cycle as waste.

\subsection{Chemical Recycling and Upcycling (Fig. 5)}

Today, the main chemical upcycling process is pyrolysis, and several chemical companies are investing in the technology (Plastic Energy, Agilyx, Quantafuel, and more).[68] Interestingly, the first pyrolysis efforts date back to the late 1940s when PMMA was pyrolyzed into its monomer constituents. ${ }^{[69]}$ Typical reaction conditions are described in Table 1, entry 1.

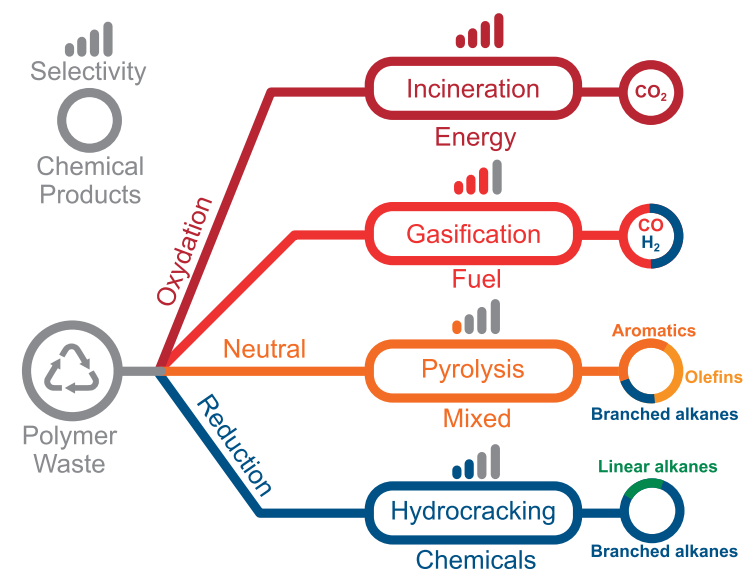

Fig. 5. Different treatment methods for end-of-life polyolefin valorization.

The advantage of pyrolysis is that it can be relatively cheap (thermal treatment in the absence of air) and widely applicable to large spectra of feedstocks, rationalizing the many pilot projects that exist around the globe. ${ }^{[11,70-72]}$ The drawback is that the cracking is not selective. This means that the product is suitable for transportation fuel applications rather than material applications, and the pyrolysis oil must be refined or blended with standard fuels (e.g. diesel) before it can be used. ${ }^{[73]}$

Gasification is another chemical upcycling process of plastic. This method involves the thermal decomposition of plastics at high temperature in a limited oxidizing atmosphere. It produces syngas - a mixture of $\mathrm{CO}$ and $\mathrm{H}_{2}$ - that can be used for power generation or for chemical synthesis. The former is the most widespread application of syngas but fuel applications are not in line with a circular economy and material recovery. For the latter, follow-up processes are required (e.g. Fischer Tropsch followed by cracking). Gasification displays high selectivity and conversion but is very energy intensive as the endothermic reactions require temperatures up to $1000{ }^{\circ} \mathrm{C}$. ${ }^{74]}$ The gasification technology has already been implemented in several pilot and industrial scale initiatives. ${ }^{[75]}$ Typical reaction conditions are described in Table 1, entry 2.

Finally, hydrocracking is an emerging chemical upcycling process of plastic. The technology today is mostly described in the academic domain. This method involves the catalytic decomposition of plastics at low temperature $\left(350-450{ }^{\circ} \mathrm{C}\right)$ under an $\mathrm{H}_{2}$ atmosphere. Hydrocracking combines the advantages of pyrolysis and gasification, namely high selectivity and conversion, and moderate requirements in energy as the reaction is only slightly endothermic. The reaction however requires hydrogen which has an energy-intensive production process. In this context, $\mathrm{H}_{2}$ production technologies, especially from renewable electricity, are currently subject to drastic improvements both in their performance and economical aspect, which would in turn increase the potential for plastic hydrocracking. ${ }^{[76]}$ Typical reaction conditions are described in Table 1, entry 3 .

The product conversion and selectivity of hydrocracking can be modified by varying catalyst, temperature, hydrogen pressure, and residence time. Several metals and supports have been investigated in the literature. In 1998, Dufaud et al. dis- 
Table 1: Typical pyrolysis, gasification, and hydrocracking reaction conditions.

\begin{tabular}{|c|c|c|c|c|c|}
\hline Entry & Tech & Feedstock & Conditions & Products & Refs \\
\hline 1 & Pyrolysis & $\begin{array}{l}\text { LDPE, HDPE, } \\
\text { PP, PS }\end{array}$ & $\begin{array}{l}\text { Decomposition in absence of } \\
\text { air, with or without a catalyst } \\
\text { (typically zeolite); high } \\
\text { temperature }\left(>500^{\circ} \mathrm{C}\right) \text {; } \\
\text { long residence time }\end{array}$ & $\begin{array}{l}\text { Liquid oil (50-80\%), gases (HC and } \\
\text { hydrogen) (15-50\%), and char } \\
(1-3 \%)\end{array}$ & {$[88,89]$} \\
\hline 2 & Gasification & $\begin{array}{l}\text { LDPE, HDPE, } \\
\text { PP, PS, PET }\end{array}$ & $\begin{array}{l}\text { Decomposition in the presence } \\
\text { of low oxygen equivalent (air, } \\
\text { oxygen, steam or } \mathrm{CO}_{2} \text { ), with } \\
\text { or without a catalyst; high } \\
\text { temperature }>800^{\circ} \mathrm{C} \text { ) }\end{array}$ & $\begin{array}{l}\text { Syngas (hydrogen and carbon } \\
\text { monoxide gas with traces of } \mathrm{CO}_{2} \text { and } \\
\mathrm{CH}_{4} \text { ), tar and non-desired gases, and } \\
\text { solid char }\end{array}$ & [75,90-92] \\
\hline 3 & Hydrocracking & $\begin{array}{l}\text { LDPE, HDPE, } \\
\text { PP, PS, PET }\end{array}$ & $\begin{array}{l}\text { Decomposition in presence } \\
\text { of hydrogen and a catalyst } \\
\text { (typically metal supported } \\
\text { catalyst); low temperature } \\
\left(300-350^{\circ} \mathrm{C}\right)\end{array}$ & $\begin{array}{l}\text { Short chain saturated paraffins } \\
\text { (methane or naphtha) }\end{array}$ & {$[81,93]$} \\
\hline
\end{tabular}

covered that zirconium hydride supported on silica-alumina $(\mathrm{Zr}$ loading of $3 \mathrm{wt} \%$ ) is able to polymerize both ethylene and propylene to the corresponding polyolefin, and completely convert the resulting polymer to light alkanes, after $62 \mathrm{~h}$, at $150{ }^{\circ} \mathrm{C}$ for PE $\left(190{ }^{\circ} \mathrm{C}\right.$ for PP) and 1 bar of $\mathrm{H}_{2}$ (substrate:catalyst weight ratio of 1.6:1).[77] More recently, Lee et al. demonstrated that ruthenium nanoparticles supported on zeolites (Ru loading of $2.5 \mathrm{wt} \%$ ) convert polyolefins (low-density polyethylene (LDPE) and PP) into grid-compatible methane in near quantitative yield (97\%) after $4 \mathrm{~h}$, at $300{ }^{\circ} \mathrm{C}$ and 50 bar of $\mathrm{H}_{2}$ (substrate:catalyst weight ratio of 16.5:1).[78] On the other hand, Rorrer et al. showed that ruthenium nanoparticles supported on carbon $(\mathrm{Ru}$ loading of $5 \mathrm{wt} \%$ ), at $200{ }^{\circ} \mathrm{C}$ and $20 \mathrm{bar}_{2}$, display a broader product distribution with $45 \%$ by mass of liquid n-alkanes and $50 \%$ by mass of gaseous alkanes after $16 \mathrm{~h}$ (substrate:catalyst weight ratio of 28:1). The same catalyst, at $250{ }^{\circ} \mathrm{C}$ and $30 \mathrm{bar}$ of $\mathrm{H}_{2}$, renders near quantitative yield of methane after $16 \mathrm{~h}$ (substrate:catalyst weight ratio of $4: 1)^{\left[{ }^{[79]}\right.}$ In yet another study, Celik et al. described a catalyst made of platinum nanoparticles supported on $\mathrm{SrTiO}_{3}$ perovskite (Pt loading of $11.1 \mathrm{wt} \%$ ) completely converting polyethylene into high-quality liquid alkanes, after $96 \mathrm{~h}$ at $300{ }^{\circ} \mathrm{C}$ and 11 bar $\mathrm{H}_{2}$ (substrate:catalyst weight ratio of $5: 1)$. ${ }^{[8]}$ The effect of various catalysts and process conditions on hydrocracking of PE and PP have been reviewed in detail in 2018 by Munir et al. ${ }^{[81]}$

When it comes to PVC, chemical recycling is more challenging than for PE and PP. Indeed, the chlorine atoms present in the polymer generate toxic and corrosive $\mathrm{HCl}$ gases that provoke equipment corrosion and catalyst degradation. PVC must therefore undergo a dechlorination/dehydrochlorination pre-treatment step. ${ }^{\left[{ }^{82}\right]}$ In this perspective, polyethylene glycol (PEG) is known to successfully catalyse the dechlorination of PVC in the presence of potassium hydroxide, with a $98 \%$ yield. ${ }^{[9]}$ This process yields polyenes suitable for further thermal treatment (pyrolysis, gasification or hydrocracking). ${ }^{[83]}$

For all the technologies described above (pyrolysis, gasification, and hydrocracking) the process conditions must be supported with careful reactor design. In the case of pyrolysis, for example, there have been reports on the utilization of rotary kilns, ${ }^{[84]}$ continuous stirred tank reactor, ${ }^{[85]}$ fluidized beds, ${ }^{[86]}$ and spouted beds. ${ }^{[87]}$ The choice of the reactor has an influence on the processing capabilities as heat and mass transfers are not controlled in the same way, leading to challenges in scaling-up the technology.

\subsection{Biocatalytic Depolymerization}

Another interesting recycling method for post-consumer plastic waste is biocatalytic depolymerization. This method relies on the utilization of microorganism enzymes to deconstruct the polymers. Recent and promising research described a bacterium, Ideonella sakaiensis, able to degrade PET plastics and use it as sole energy and carbon source. They identified the extracellular enzymes responsible for this activity: a PET hydrolase (PETase) cleaving PET into mono(2-hydroxyethyl) terephthalic acid (MHET); and a MHET hydrolase (MHETase) further cleaving MHET into terephthalic acid and ethylene glycol, the original building blocks of PET. ${ }^{[94]}$ Another study showed that PETases are also able to degrade PEF, the promising bio-sourced replacement to PET described above, into hydroxyethyl-2,5-furandicarboxylate. They also anticipated that guided mutagenesis of MHETase would enable to reach the original building blocks of PEF: FDCA and ethylene glycol. ${ }^{[95]}$ Further research aims at improving the degradation activity and thermal stability of enzymes variants through protein engineering, ${ }^{[96]}$ and at expressing these enzymes in other microorganisms, such as photosynthetic microalga.[97]

In addition, Tournier $e t$ al. have isolated and improved a leafbranch compost cutinase (LCC) enzyme that degrades PET to monomers with unprecedented productivity. ${ }^{[98]}$ Their technology has been successfully applied to $150 \mathrm{~L}$ pilot scale bioreactors and is currently scaled up to industrial production by Carbios, with an expected beginning of operations by the end of 2021 .

In parallel, multiple fungi and bacteria have also been identified for the degradation of polyester polyurethane through enzymatic depolymerization. ${ }^{[99]}$ Especially, a fungus, Pestalotiopsis microspore, is able to use PUR as its sole carbon source, both in aerobic and anaerobic conditions. Its extracellular hydrolases break the ester bond of the synthetic polymer, and make the products available for further metabolization by the fungi. ${ }^{[100]}$

\section{Life Cycle Assessment (LCA) Considerations}

With the rise of multiple short-lived plastic recycling methods, the field of LCA is becoming an indispensable tool to assess the overall impact of a process. An LCA is a comparative analysis wherein a proposed process must be rated relatively to a suitable benchmark. This can lead to some degree of uncertainty in the field of waste management as the benchmark technology can vary from one geographical region to another. For example, Switzerland predominantly incinerates its plastic waste $(73 \%$ of plastic post- 
Fig. 6. Grading system for plastic waste as function of origin and treatment method.

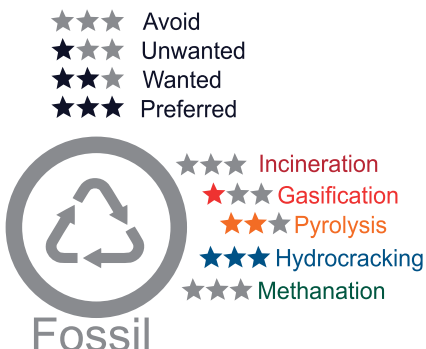

Fossil

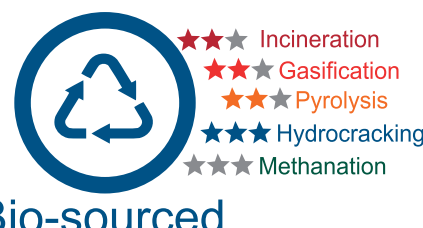

Bio-sourced

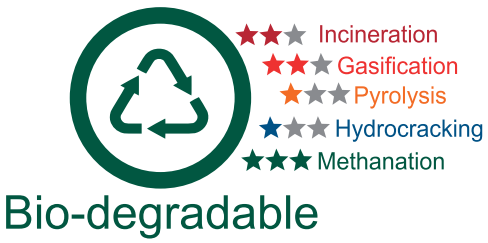

Bio-degradable consumer waste in 2018) and uses the heat to provide district heating and electricity. ${ }^{[4]}$ At the same time, Switzerland generates large quantities of renewable electricity (59\% in 2019), [101] making the comparative analysis between electricity production unfavourable for incineration, and exemplifies the importance of selecting a suitable comparison metric. Further, the infrastructure in Switzerland is equipped with state-of-the-art pollution control catalysts, leading to reduced emissions. A Swiss incinerator will not result in the same impact for plastic incineration than an incinerator that is not equipped with suitable pollution control and for which emissions will be much higher. The above cited example is one of the reasons why LCA can spark debate. For instance, BASF provided an LCA (conducted by Sphera Solutions $\mathrm{GmbH}$ ) for their ChemCycling ${ }^{\mathrm{TM}}$ process in which they demonstrate positive impact of waste pyrolysis with respect to incineration - namely a $50 \%$ decrease of $\mathrm{CO}_{2}$ emissions. ${ }^{[66]}$ This analysis - and few others - were later criticized by Zero Waste Europe, a network of environmental NGOs, for undisclosed datasets, selective presentation of results, and flawed assumptions. ${ }^{[102]}$ Regardless, LCA should be routinely conducted early on in a project as it can shed light on aspects that must be improved to reach sustainability targets, and can sometimes result in counter-intuitive results that should not be disregarded. One notable example is the preferred utilization of single-use plastic yoghourt pots over glass pots owing to the weight of the materials during transport. ${ }^{[103]}$

\section{Conclusions and Outlook}

The transition from a linear plastic consumption model to a circular model will require the collaboration of the entire value chain, starting with product design and finishing with product end-of-life. The chemical structures that make up plastic must be homogenized and designed for recycling, albeit without compromising on the quality of the material. The part of bio-sourced plastics should increase but must go hand-in-hand with efficient end-of-life strategies. Collection and sorting must be improved so that the feedstock specification match current and emerging technologies. This can be achieved through various means and technologies (e.g. infrared spectroscopy coupled with cameras for colour determination). Emerging technologies must focus on delivering clean products that can ideally be processed in existing assets to decrease the overall capital expenditure. Finally, all this must be undertaken by considering the LCA of the processes as well as the economics of the emerging processes. Fig. 6 attempts to show that end-of-life strategies of plastics may differ depending on their origin and properties (bio-derived, fossil-derived or biodegradable). Finally, achieving results will not be possible with a 'one size fits all' solution but rather from a collaborative approach among the key industrial and academic players in the field.

Received: May 14, 2021

[1] R. C. Thompson, S. H. Swan, C. J. Moore, F. S. vom Saal, Philos. Trans. R. Soc. B Biol. Sci. 2009, 364, 1973, https://doi.org/10.1098/rstb.2009.0054.

[2] P. Dauvergne, Glob. Environ. Chang. 2018, 51, 22, https://doi.org/10.1016/j.gloenvcha.2018.05.002.
[3] Statista, 'Distribution of plastic production worldwide in 2018, by type', https://www.statista.com/statistics/968808/distribution-of-global-plasticproduction-by-type/, accessed May 5, 2021.

[4] Plastics Europe, 'Plastics - the Facts 2020', 2020.

[5] T. D. Nielsen, J. Hasselbalch, K. Holmberg, J. Stripple, WIREs Energy Environ. 2020, 9, 360, https://doi.org/10.1002/wene.360.

[6] R. Geyer, in 'Plastic Waste and Recycling', Elsevier, 2020, pp. 13-32.

[7] E. De Tandt, C. Demuytere, E. Van Asbroeck, H. Moerman, N. Mys, G. Vyncke, L. Delva, A. Vermeulen, P. Ragaert, S. De Meester, K. Ragaert, Waste Manag. 2021, 119, 315, https://doi.org/10.1016/j.wasman.2020.10.012.

[8] L. Shen, E. Worrell, in 'Handbook of Recycling', Elsevier, 2014, pp. 179-190.

[9] S. C. Kosloski-Oh, Z. A. Wood, Y. Manjarrez, J. P. de los Rios, M. E. Fieser, Mater. Horiz. 2021, 8, 1084, https://doi.org/10.1039/D0MH01286F.

[10] K. Ragaert, L. Delva, K. Van Geem, Waste Manag. 2017, 69, 24 , https://doi.org/10.1016/j.wasman.2017.07.044.

[11] J. M. Garcia, M. L. Robertson, Science 2017, 358, 870, https://doi.org/10.1126/science.aaq0324.

[12] Y. Saeki, T. Emura, Prog. Polym. Sci. 2002, 27, 2055, https://doi.org/10.1016/S0079-6700(02)00039-4.

[13] A. Gandini, D. Coelho, M. Gomes, B. Reis, A. Silvestre, J. Mater. Chem. 2009, 19, 8656, https://doi.org/10.1039/B909377J.

[14] F. W. Gomes, R. C. Lima, C. R. Piombini, J. F. Sinfitele, F. G. de Souza, P. L. A. Coutinho, J. C. Pinto, Macromol. Symp. 2018, 381, 1800129, https://doi.org/10.1002/masy.201800129.

[15] J -G. Rosenboom, D. K. Hohl, P. Fleckenstein, G. Storti, M. Morbidelli, Nat Commun. 2018, 9, 2701, https://doi.org/10.1038/s41467-018-05147-y.

[16] S. K. Burgess, J. E. Leisen, B. E. Kraftschik, C. R. Mubarak, R. M. Kriegel, W. J. Koros, Macromolecules 2014, 47, 1383, https://doi.org/10.1021/ma5000199.

[17] X. Chen, N. Yan, Mater. Today Sustain. 2020, 7-8, 100031 , https://doi.org/10.1016/j.mtsust.2019.100031.

[18] P. T. Benavides, U. Lee, O. Zarè-Mehrjerdi, J. Clean. Prod. 2020, 277, 124010, https://doi.org/10.1016/j.jclepro.2020.124010.

[19] F. D. Bobbink, A. P. van Muyden, P. J. Dyson, Chem. Commun. 2019, 55, 1360, https://doi.org/10.1039/C8CC07907B.

[20] G. T. Beckham, C. W. Johnson, E. M. Karp, D. Salvachúa, D. R. Vardon, Curr. Opin. Biotechnol. 2016, 42, 40, https://doi.org/10.1016/j.copbio.2016.02.030.

[21] L. Shuai, M. T. Amiri, Y. M. Questell-Santiago, F. Héroguel, Y. Li, H. Kim, R. Meilan, C. Chapple, J. Ralph, J. S. Luterbacher, Science 2016, 354, 329 , https://doi.org/10.1126/science.aaf7810.

[22] Y. Pierson, X. Chen, F. D. Bobbink, J. Zhang, N. Yan, ACS Sustain. Chem. Eng. 2014, 2, 2081, https://doi.org/10.1021/sc500334b.

[23] A. P. Van Muyden, Doctoral dissertation, EPFL, Lausanne, 2020.

[24] C. Liptow, A.-M. Tillman, J. Ind. Ecol. 2012, 16, 420, https://doi.org/10.1111/j.1530-9290.2011.00405.x

[25] I. Tsiropoulos, A. P. C. Faaij, J. E. A. Seabra, L. Lundquist, U. Schenker, J. F. Briois, M. K. Patel, Int. J. Life Cycle Assess. 2014, 19, 1049, https://doi.org/10.1007/s11367-014-0714-5.

[26] M. Rose, R. Palkovits, Macromol. Rapid Commun. 2011, 32, 1299 , https://doi.org/10.1002/marc.201100230.

[27] L. Zhang, G. Xi, Z. Chen, Z. Qi, X. Wang, Chem. Eng. J. 2017, 307, 877, https://doi.org/10.1016/j.cej.2016.09.003.

[28] S. Siankevich, Z. Fei, R. Scopelliti, P. G. Jessop, J. Zhang, N. Yan, P. J. Dyson, ChemSusChem 2016, 9, 2089, https://doi.org/10.1002/ cssc. 201600313.

[29] T. Deng, X. Cui, Y. Qi, Y. Wang, X. Hou, Y. Zhu, Chem. Commun. 2012, 48 , 5494, https://doi.org/10.1039/C2CC00122E.

[30] F. D. Bobbink, Z. Huang, F. Menoud, P. J. Dyson, ChemSusChem 2019, 12, 1437, https://doi.org/10.1002/cssc.201802830.

[31] K. V. Venkatesh, Bioresour. Technol. 1997, 62, 91, https://doi.org/10.1016/S0960-8524(97)00122-3.

[32] Y. Wang, W. Deng, B. Wang, Q. Zhang, X. Wan, Z. Tang, Y. Wang, C. Zhu, Z. Cao, G. Wang, H. Wan, Nat. Commun. 2013, 4, 2141, https://doi.org/10.1038/ncomms3141.

[33] S. Jacobsen, H. G. Fritz, P. Degée, P. Dubois, R. Jérôme, Polym. Eng. Sci. 1999, 39, 1311, https://doi.org/10.1002/pen.11518. 
[34] J. Artz, R. Palkovits, Curr. Opin. Green Sustain. Chem. 2018, 14, 14 https://doi.org/10.1016/j.cogsc.2018.05.005.

[35] F. A. Castillo Martinez, E. M. Balciunas, J. M. Salgado, J. M. Domínguez González, A. Converti, R. P. de S. Oliveira, Trends Food Sci. Technol. 2013, 30, 70, https://doi.org/10.1016/j.tifs.2012.11.007.

[36] M. Jamshidian, E. A. Tehrany, M. Imran, M. Jacquot, S Desobry, Compr. Rev. Food Sci. Food Saf. 2010, 9, 552, https://doi.org/10.1111/j.1541-4337.2010.00126.x.

[37] P. C. Sabapathy, S. Devaraj, K. Meixner, P. Anburajan, P. Kathirvel, Y. Ravikumar, H. M. Zabed, X. Qi, Bioresour. Technol. 2020, 306, 123132, https://doi.org/10.1016/j.biortech.2020.123132.

[38] K. Budak, O. Sogut, U. Aydemir Sezer, J. Polym. Res. 2020, 27, 208, https://doi.org/10.1007/s10965-020-02187-1.

[39] E. S. Sanz-Pérez, C. R. Murdock, S. A. Didas, C. W. Jones, Chem. Rev. 2016, 116, 11840, https://doi.org/10.1021/acs.chemrev.6b00173.

[40] S. Gardarsdottir, E. De Lena, M. Romano, S. Roussanaly, M. Voldsund, J.-F. Pérez-Calvo, D. Berstad, C. Fu, R. Anantharaman, D. Sutter, M. Gazzani, M. Mazzotti, G. Cinti, Energies 2019, 12, 542, https://doi.org/10.3390/en12030542.

[41] A. Al-Mamoori, A. Krishnamurthy, A. A. Rownaghi, F. Rezaei, Energy Technol. 2017, 5, 834, https://doi.org/10.1002/ente.201600747.

[42] Climeworks, 'Breaking the record for the largest ever investment into direct air capture', https://climeworks.com/news/recent-investment-inclimeworks-has-been-boosted-from, accessed May 5, 2021.

[43] F. Karimi, A. Goulas, M. M. Barzmehri, M. A. Putri, Int. J. Sustain. Water Environ. Syst. 2012, 4, 23,

[44] A. Singh, K. Stéphenne, Energy Procedia 2014, 63, 1678, https://doi.org/10.1016/j.egypro.2014.11.177.

[45] J. Urech, L. Tock, T. Harkin, A. Hoadley, F. Maréchal, Energy 2014, 64, 268, https://doi.org/10.1016/j.energy.2013.10.081.

[46] F. Li, A. Thevenon, A. Rosas-Hernández, Z. Wang, Y. Li, C. M. Gabardo, A. Ozden, C. T. Dinh, J. Li, Y. Wang, J. P. Edwards, Y. Xu, C. McCallum, L. Tao, Z.-Q. Liang, M. Luo, X. Wang, H. Li, C. P. O’Brien, C.-S. Tan, D.-H Nam, R. Quintero-Bermudez, T.-T. Zhuang, Y. C. Li, Z. Han, R. D. Britt, D. Sinton, T. Agapie, J. C. Peters, E. H. Sargent, Nature 2020, 577, 509, https://doi.org/10.1038/s41586-019-1782-2.

[47] C.-T. Dinh, T. Burdyny, M. G. Kibria, A. Seifitokaldani, C. M. Gabardo, F. P. García de Arquer, A. Kiani, J. P. Edwards, P. De Luna, O. S. Bushuyev, C. Zou, R. Quintero-Bermudez, Y. Pang, D. Sinton, E. H. Sargent, Science 2018, 360, 783, https://doi.org/10.1126/science. aas9100

[48] Y. Wang, H. Shen, K. J. T. Livi, D. Raciti, H. Zong, J. Gregg, M. Onadeko, Y. Wan, A. Watson, C. Wang, Nano Lett. 2019, 19, 8461 , https://doi.org/10.1021/acs.nanolett.9b02748.

[49] T. K. Todorova, M. W. Schreiber, M. Fontecave, ACS Catal. 2020, 10 , 1754, https://doi.org/10.1021/acscatal.9b04746.

[50] X. Wang, J. F. de Araújo, W. Ju, A. Bagger, H. Schmies, S. Kühl, J. Rossmeis1, P. Strasser, Nat. Nanotechnol. 2019, 14, 1063, https://doi.org/10.1038/s41565-019-0551-6.

[51] S. C. Perry, C. Ponce de León, F. C. Walsh, J. Electrochem. Soc. 2020, 167, 155525, https://doi.org/10.1149/1945-7111/abc58e

[52] S. Nitopi, E. Bertheussen, S. B. Scott, X. Liu, A. K. Engstfeld, S. Horch, B. Seger, I. E. L. Stephens, K. Chan, C. Hahn, J. K. Nørskov, T. F. Jaramillo, I. Chorkendorff, Chem. Rev. 2019, 119, 7610, https://doi.org/10.1021/acs.chemrev.8b00705.

[53] T. Zheng, K. Jiang, H. Wang, Adv. Mater. 2018, 30, 1802066, https://doi.org/10.1002/adma.201802066

[54] I. J. C. Geerlings, M. C. Zonnevylle, C. P. M. De Groot, Catal. Lett. 1990, 5, 309, https://doi.org/10.1007/BF00764676.

[55] F. Pontzen, W. Liebner, V. Gronemann, M. Rothaemel, B. Ahlers, Catal. Today 2011, 171, 242, https://doi.org/10.1016/j.cattod.2011.04.049.

[56] P. Tian, Y. Wei, M. Ye, Z. Liu, ACS Catal. 2015, 5, 1922, https://doi.org/10.1021/acscatal.5b00007

[57] S. G. Jadhav, P. D. Vaidya, B. M. Bhanage, J. B. Joshi, Chem. Eng. Res. Des. 2014, 92, 2557, https://doi.org/10.1016/J.CHERD.2014.03.005.

[58]F. Studt, I. Sharafutdinov, F.Abild-Pedersen, C. F. Elkjær, J. S. Hummelshøj, S. Dahl, I. Chorkendorff, J. K. Nørskov, Nat. Chem. 2014, 6, 320, https://doi.org/10.1038/nchem.1873.

[59] S. Xu, Y. Zhi, J. Han, W. Zhang, X. Wu, T. Sun, Y. Wei, Z. Liu, in 'Advances in Catalysis', Academic Press Inc., 2017, vol. 61, pp. 37122.

[60] M. Yang, D. Fan, Y. Wei, P. Tian, Z. Liu, Adv. Mater. 2019, 31, 1902181 , https://doi.org/10.1002/adma.201902181.

[61] C. Trakunjae, A. Boondaeng, W. Apiwatanapiwat, A. Kosugi, T. Arai, K. Sudesh, P. Vaithanomsat, Sci. Rep. 2021, 11, 1896 , https://doi.org/10.1038/s41598-021-81386-2

[62] N. J. Claassens, D. Z. Sousa, V. A. P. M. Dos Santos, W. M De Vos, J. Van Der Oost, Nat. Rev. Microbiol. 2016, 14, 692, https://doi.org/10.1038/nrmicro.2016.130.

[63] L. Garcia-Gonzalez, H. De Wever, FEMS Microbiol. Lett. 2017, 364, 196, https://doi.org/10.1093/femsle/fnx196.
[64] H. Roh, J. S. Lee, H. Il Choi, Y. J. Sung, S. Y. Choi, H. M. Woo, S. J. Sim, Bioresour. Technol. 2021, 327, 124789 , https://doi.org/10.1016/j.biortech.2021.124789.

[65] W. W. Y. Lau, Y. Shiran, R. M. Bailey, E. Cook, M. R. Stuchtey, J. Koskella, C. A. Velis, L. Godfrey, J. Boucher, M. B. Murphy, R. C. Thompson, E. Jankowska, A. Castillo Castillo, T. D. Pilditch, B. Dixon, L. Koerselman, E. Kosior, E. Favoino, J. Gutberlet, S. Baulch, M. E. Atreya, D. Fischer, K. K. He, M. M. Petit, U. R. Sumaila, E. Neil, M. V. Bernhofen, K. Lawrence, J. E. Palardy, Science 2020, 369, 1455, https:// doi.org/10.1126/science.aba9475.

[66] H. Jeswani, C. Krüger, M. Russ, M. Horlacher, F. Antony, S Hann, A. Azapagic, Sci. Total Environ. 2021, 769, 144483 https://doi.org/10.1016/j.scitotenv.2020.144483.

[67] H. H. Khoo, Resour. Conserv. Recycl. 2019, 145, 67, https://doi.org/10.1016/j.resconrec.2019.02.010.

[68] A. H. Tullo, C\&EN Glob. Enterp. 2019, 97, 29,

[69] M. Isador, A. L. Beiser, 'Art of reclaiming plastic scrap', US2470361, 1945.

[70] W. Sriningsih, M. G. Saerodji, W. Trisunaryanti, Triyono, R Armunanto, I. I. Falah, Proc. Environ. Sci. 2014, 20, 215 https://doi.org/10.1016/j.proenv.2014.03.028.

[71] D. P. Serrano, J. M. Escola, L. Briones, S. Medina, A. Martínez, Fuel 2015, 144, 287, https://doi.org/10.1016/j.fuel.2014.12.040.

[72] M. Heidari, P. P. Garnaik, A. Dutta, in 'Plastics to Energy', Elsevier, 2019, pp. 295-312.

[73] I. Kalargaris, G. Tian, S. Gu, Fuel Process. Technol. 2017, 157, 108, https://doi.org/10.1016/j.fuproc.2016.11.016.

[74] A. Brems, R. Dewil, J. Baeyens, R. Zhang, Nat. Sci. 2013, 05, 695,

[75] S. A. Salaudeen, P. Arku and A. Dutta, in 'Plastics to Energy', Elsevier, 2019, pp. 269-293.

[76] I. Staffell, D. Scamman, A. Velazquez Abad, P. Balcombe, P. E. Dodds, P. Ekins, N. Shah, K. R. Ward, Energy Environ. Sci. 2019, 12, 463, https://doi.org/10.1039/C8EE01157E.

[77] V. Dufaud, J.-M. Basset, Angew. Chemie Int. Ed. 1998, 37, 806, https://doi.org/10.1002/(SICI)1521-3773(19980403)37:6<806::AIDANIE806>3.0.CO;2-6.

[78] W.-T. Lee, F. D. Bobbink, A. P. van Muyden, K.-H. Lin, C. Corminboeuf, R. R. Zamani, P. J. Dyson, Cell Reports Phys. Sci. 2021, 2, 100332, https://doi.org/10.1016/j.xcrp.2021.100332.

[79] J. E. Rorrer, G. T. Beckham, Y. Román-Leshkov, JACS Аи 2021, 1, 8 , https://doi.org/10.1021/jacsau.0c00041

[80] G. Celik, R. M. Kennedy, R. A. Hackler, M. Ferrandon, A. Tennakoon, S. Patnaik, A. M. LaPointe, S. C. Ammal, A. Heyden, F. A. Perras, M. Pruski, S. L. Scott, K. R. Poeppelmeier, A. D. Sadow, M. Delferro, ACS Cent. Sci. 2019, 5, 1795, https://doi.org/10.1021/acscentsci.9b00722.

[81] D. Munir, M. F. Irfan, M. R. Usman, Renew. Sustain. Energy Rev. 2018, 90, 490, https://doi.org/10.1016/j.rser.2018.03.034

[82] I. Vollmer, M. J. F. Jenks, M. C. P. Roelands, R. J. White, T. Harmelen, P. Wild, G. P. Laan, F. Meirer, J. T. F. Keurentjes, B. M. Weckhuysen, Angew. Chemie Int. Ed. 2020, 59, 15402, https://doi.org/10.1002/ anie. 201915651

[83] J. Yu, L. Sun, C. Ma, Y. Qiao, H. Yao, Waste Manag. 2016, 48, 300, https://doi.org/10.1016/j.wasman.2015.11.041.

[84] Y. Zhang, G. Ji, C. Chen, Y. Wang, W. Wang, A. Li, Fuel Process. Technol. 2020, 206, 106455, https://doi.org/10.1016/j.fuproc.2020.106455.

[85] A. R. Auxilio, W.-L. Choo, I. Kohli, S. Chakravartula Srivatsa, S. Bhattacharya, Waste Manag. 2017, 67, 143, https://doi.org/10.1016/j.wasman.2017.05.011.

[86] M. L. Mastellone, F. Perugini, M. Ponte, U. Arena, Polym. Degrad. Stab. 2002, 76, 479, https://doi.org/10.1016/S0141-3910(02)00052-6.

[87] R. Aguado, R. Prieto, M. J. S. José, S. Alvarez, M. Olazar, J. Bilbao, Chem. Eng. Process. Process Intensif. 2005, 44, 231, https://doi.org/10.1016/j.cep.2004.02.016.

[88] R. Miandad, M. A. Barakat, A. S. Aburiazaiza, M. Rehan, A. S. Nizami, Process Saf. Environ. Prot. 2016, 102, 822, https://doi.org/10.1016/j.psep.2016.06.022.

[89] S. D. Anuar Sharuddin, F. Abnisa, W. M. A. Wan Daud, M. K. Aroua, Energy Convers. Manag. 2016, 115, 308, https://doi.org/10.1016/j.enconman.2016.02.037.

[90] G. Lopez, M. Artetxe, M. Amutio, J. Alvarez, J. Bilbao, M. Olazar, Renew. Sustain. Energy Rev. 2018, 82, 576, https://doi.org/10.1016/j.rser.2017.09.032.

[91] C. Wu, P. T. Williams, Fuel 2010, 89, 3022, https://doi.org/10.1016/j.fuel.2010.05.032.

[92] R. Xiao, B. Jin, H. Zhou, Z. Zhong, M. Zhang, Energy Convers. Manag. 2007, 48, 778, https://doi.org/10.1016/j.enconman.2006.09.004.

[93] W. Ding, J. Liang, L. L. Anderson, Energy \& Fuels 1997, 11, 1219, https://doi.org/10.1021/ef970051q.

[94] S. Yoshida, K. Hiraga, T. Takehana, I. Taniguchi, H. Yamaji, Y. Maeda, K. Toyohara, K. Miyamoto, Y. Kimura, K. Oda, Science 2016, 351, 1196 , https://doi.org/10.1126/science.aad6359. 
[95] G. J. Palm, L. Reisky, D. Böttcher, H. Müller, E. A. P. Michels, M. C. Walczak, L. Berndt, M. S. Weiss, U. T. Bornscheuer, G. Weber, Nat. Commun. 2019, 10, 1717, https://doi.org/0.1038/s41467-019-09326-3

[96] H. F. Son, I. J. Cho, S. Joo, H. Seo, H.-Y. Sagong, S. Y. Choi, S. Y. Lee, K.-J. Kim, ACS Catal. 2019, 9, 3519, https://doi.org/10.1021/acscatal.9b00568.

[97] D. Moog, J. Schmitt, J. Senger, J. Zarzycki, K.-H. Rexer, U. Linne, T. Erb, U. G. Maier, Microb. Cell Fact. 2019, 18, 171, https://doi.org/10.1186/s12934-019-1220-z.

[98] V. Tournier, C. M. Topham, A. Gilles, B. David, C. Folgoas, E. MoyaLeclair, E. Kamionka, M. L. Desrousseaux, H. Texier, S. Gavalda, M. Cot, E. Guémard, M. Dalibey, J. Nomme, G. Cioci, S. Barbe, M. Chateau, I. André, S. Duquesne, A. Marty, Nature 2020, 580, 216, https://doi.org/10.1038/s41586-020-2149-4.

[99] T. Nakajima-Kambe, Y. Shigeno-Akutsu, N. Nomura, F. Onuma, T. Nakahara, Appl. Microbiol. Biotechnol. 1999, 51, 134, https://doi.org/10.1007/s002530051373.

[100] J. R. Russell, J. Huang, P. Anand, K. Kucera, A. G. Sandoval, K. W. Dantzler, D. Hickman, J. Jee, F. M. Kimovec, D. Koppstein, D. H. Marks, P. A. Mittermiller, S. J. Núñez, M. Santiago, M. A. Townes, M. Vishnevetsky, N. E. Williams, M. P. N. Vargas, L.-A. Boulanger, C. Bascom-Slack, S. A. Strobel, Appl. Environ. Microbiol. 2011, 77, 6076, https://doi.org/10.1128/AEM.00521-11.
[101] International Energy Agency, 'Electricity Generation By Source Switzerland', https://www.iea.org/countries/switzerland, accessed May 5, 2021.

[102] Zero Waste Europe, 'Understanding the Environmental Impacts of Chemical Recycling - ten concerns with existing life cycle assessments', 2020.

[103] S. Humbert, V. Rossi, M. Margni, O. Jolliet, Y. Loerincik, Int. J. Life Cycle Assess. 2009, 14, 95, https://doi.org/10.1007/s11367-008-0052-6.

\section{License and Terms}

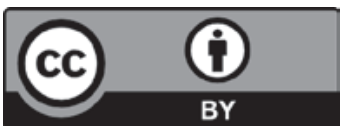

This is an Open Access article under the terms of the Creative Commons Attribution License CC BY 4.0. The material may not be used for commercial purposes.

The license is subject to the CHIMIA terms and conditions: (http:// chimia.ch/component/sppagebuilder/?view=page \&id=12).

The definitive version of this article is the electronic one that can be found at https://doi.org/10.2533/chimia.2021.744 